\title{
M.Phil. as Masters by Research Work Programs in IT \& Computing Fields: A Case Study of Indian Private Universities
}

\author{
P. K. Paul ${ }^{1}$, P. S. Aithal ${ }^{2}$ and K. S. Shivraj ${ }^{3}$ \\ ${ }^{1}$ Raiganj University (RGU), West Bengal, India \\ ${ }^{2}$ Vice-Chancellor, Srinivas University, Karnataka, India \\ ${ }^{3}$ Head-Learning Resource Centre, KL University, Andhra Pradesh, India \\ E-Mail: pkpaul.infotech@gmail.com
}

\begin{abstract}
Indian higher education system is changing rapidly. During the last few decades after Independence of India, several educational institutions have been developed throughout the nation. During this period apart from the establishment of HEIs various new degrees, diplomas and awards have been started. Like the United Kingdom and its follower countries, degrees in the field of Science and Applied Sciences started and continued both Science and Engineering platform/ stream. Similarly, in research segment two main degrees till continued one is Doctor of Philosophy (PhD) and another is Master of Philosophy (M.Phil.). Both are important and valuable in their own place. The M.Phil. program is a kind of research based master's program and similar to the Masters of Research (M.Res.) programs available in many countries. M.Phil. is also a smaller and previous part of Doctor of Philosophy (PhD). Normally it requires less time than a PhD program. The program available worldwide and in India also it has offered by the universities. In India, the degree is available in different platform or stream i.e. Arts, Science, and Commerce. Even in Technology and Management stream as well the programs have been started in recent. This paper is conceptual in nature and primary study based on the availability of M.Phil. program nationwide. The research work mainly focuses on the varieties of M.Phil. programs available in IT and Computer fields and especially offered by Private Universities in India.

Keywords: M.Phil., PhD, Research Degree, Indian Higher Education, Research \& Development, Universities, M.Res, M.Tech. (Research), UGC Norms, Private Universities
\end{abstract}

\section{INTRODUCTION}

The M.Phil. degree is a Masters level degree and also a kind of research degree available worldwide. The Degree sometimes also abbreviated as Ph.M and in Latin, it is also called as Magister Philosophiae or Philosophiae Magister. It is thus an advanced Masters Degree with a research focus. In some of the countries, an M.Phil. is must before pursuing $\mathrm{PhD}$ Degree while in some other cases M.Phil. provides an additional weight to the degree holders. Normally, an M.Phil. is purely research based and completed after submission of Thesis or Dissertation. However, in some of the universities, it is both coursework and research work based degree. In United Kingdom and some of the countries, M.Phil. is offered after several years of full-time study. Though, part-time basis program on M.Phil. is also offered. Regardless of Full Time or Part Time, an M.Phil. is offered after defense and viva voce in most of the universities worldwide. While worldwide M.Phil. is a 2 Years program (average) but in India M.Phil. program is a 1 Year program and offered mainly regular basis. Though, the degree may also offer on a Part-Time basis with additional time of 1 Year. It is worthy to mention that an M.Phil. in India comprises both course-work and researchwork [1], [4]. Hence it is not only a research work based degree available in some of the UK and Australian Universities. In some of the universities in India M.Phil. is a must before enrollment of a $\mathrm{PhD}$ degree and in some cases, the additional pre-research degree is must or transferred into Ph.D, for example, JNU, New Delhi, India.

In India M.Phil. normally offered in the field of Science, Humanities, and Commerce, while $\mathrm{PhD}$ is additionally offered in all remaining streams viz. Engineering, Medicine, Dentistry, Pharmacy, Nursing, Veterinary Science etc. Additionally few subjects are offered both in Science and Engineering platform in India viz. Computer Science, Information Technology and allied fields (in Electronics as well it is offered an M.Tech. and MSc). Hence many universities in India have started M.Phil. in the Computing and IT fields due to its dual existence but it is not common in other streams viz. Civil Engineering or Mechanical Engineering etc. Though an M.Tech. in Computer Science and Engineering can easily grab the opportunities of M.Phil. in the related field! Private Universities are also doing well in this respect of offering M.Phil. in IT and Computing related areas in recent past [2], [5]. This study provides a detailed picture on offering M.Phil. degree in the field of Computing and IT in Indian Context.

\section{OBJECTIVES AND AGENDA}

The Paper is contextual and conceptual in nature and thus deals with following features and aim and objective in a brief manner: 
1. To learn about the M.Phil. Program available and offered in worldwide with basics of overview, nature, duration, nomenclature etc.

2. To get the knowledge on M.Phil. program offered in India and its comparison with rest world in different parameters.

3. To learn about the IT and Computing fields and their available degrees in India with reference to Research Degree.

4. To learn about the M.Phil. Degree and allied degrees available in India such as M.Tech. (Research) in IT and computing areas.

5. To dig out the knowledge on M.Phil. degrees with reference to the Private Universities in India.

\section{METHODOLOGIES ADOPTED}

The paper is observation based and conceptual as well. It is a primary research and concentrated on research degrees leading to M.Phil. in Indian Universities. More specifically for doing this research work several methods of social sciences and educational methodologies have been adopted. In primary sense review of literature played an important and valuable role in gathering basic knowledge in respect of Degrees available worldwide and India. In the later stage of the research work, web review is deployed. As the study is concentrated on private universities in India thus all the private universities have been reviewed in between August, 2017 to November, 2017. Rather searching individual private university name one core URL (http://www.ugc.ac.in/privatuniversity.aspx) is selected i.e. UGC (Government of India) for instant, authentic list of private universities and also to the identification of M.Phil. degrees in those universities.

\section{INDIAN ACADEMIC DEGREES}

Indian Universities are regulated and governed by the University Grants Commission (UGC), Govt. of India and in India there are four types of universities viz. Central University, State University, Deemed to be University, Private University as a whole total number of universities crossed over 800 (as on October, 2017). Significantly the nomenclature and degree of all the universities basically governed by the UGC and for all the universities the awarding power is same and equal [3], [6], [8]. Most of these universities offer following types of general and professional degrees including research degrees.

\section{A. General Degrees}

In General Stream like other universities, private universities also offer the following programs [7]-

1. B.A. (Bachelor of Arts)

2. B.Sc. (Bachelor of Science)

3. B.Com. (Bachelor of Commerce)

4. M.A. (Masters of Arts)

5. M.Sc. (Masters of Science)

6. M.Com. (Masters of Commerce)

\section{B. Professional Degrees}

In professional Stream like other universities, private universities also offer the following programs-

1. B.Ed. (Bachelor of Education)

2. M.Ed. (Bachelor of Education)

3. MCA (Master of Computer Applications)

4. MBA (Master of Business Administration)

Though following degrees are offered in professional colleges but awarded from the University and even many universities are offering the following program as oncampus basis. Hence in private universities as well the following degrees are common and awarded.

\section{Medicine}

1. MBBS (Bachelor of Medicine and Bachelor of Surgeon)

2. MD (Doctor of Medicine)

3. MS (Master of Surgeon)

D. Laws

1. LLB. (Bachelor of Education)

2. LLM

3. Joint LLB (Double Degrees)

4. LLD (Doctor of Laws)

E. Pharmacy

1. B.Pharm. (Bachelor of Pharmacy)

2. M.Pharm. (Master of Education)

3. Pharm. D. (Doctor of Pharmacy) [7]

F. Designing

1. B. Design (Bachelor of Design)

2. M. Design. (Master of Design)

G. Vocational Studies

1. B. Voc. (Bachelor of Vocation)

2. M. Voc. (Master of Vocation)

\section{H. Engineering Degrees}

1. B. Tech (Bachelor of Technology)

2. M. Tech (Master of Technology)

3. BE (Bachelor of Engineering)

4. ME (Master of Engineering)

5. M.Tech. (Research)

\section{RESEARCH DEGREES}

Worldwide common research degrees are Doctor of Philosophy and normally abbreviated as $\mathrm{PhD}$ and in some universities, it is also called as DPhil. In UK and some of its follower countries, the program is fully research based and 
offered after the submission of the thesis. While in US and its follower countries PhD is offered as Coursework and Research Work.

Significantly the duration of the program is 4 to 5 Years and available as Full Time and Part Time mode of study. PhD in United States is combined with Course-work and Researchwork. And during the period of study, a maximum credit and period spent on the Course-Work [4], [9], [10]. In India, $\mathrm{PhD}$ is also combined and Course-work and Research-work based but Course-Work component is relatively less (normally a semester based and with about 8 to 13 credit based). However in India few other degrees are also available:

1. M.Phil. (Master of Philosophy): The degree is treated as less than PhD degree and more than taught Master's degree. To move a $\mathrm{PhD}$ many a times researcher choose an M.Phil. degree.

2. M.Tech (Research): It is the Master of Technology by Research degree offered similar to the M.Phil. degree. As M.Phil. is offered to the candidates of Science, Humanities, and Commerce, there is no scope from the Engineering and Technological students for pursuing Research Centric Masters and to solve this, many Indian Universities (also few countries) have started to offer M.Tech. program with research concentration. It is offered as a combination of coursework and thesis work, or a combination of publications and thesis work.

3. D.Sc. (Doctor of Science): This is available in many parts of the world and mainly UK follower countries. This is treated as a Post-Doctoral Degree and offers after PhD Degree. However, it is important to note that few universities allow Masters Candidates for the DSc degree registration. The degree is offered as a PostDoctoral thesis work or Post-Doctoral publications in the form of thesis work.

4. D.Litt. (Doctor of Literature): Similar to D.Sc degree the D.Litt. degree offered in Indian Universities. The norms and other guidelines are more or less similar to the above one.

\section{A. M.Phil. and Masters by Research}

M.Phil. program is offered in India is governed by the Rules and Regulations prescribed by the University Grants Commission (UGC), Government of India. The first norms for M.Phil. program were prescribed in the year 2009 and later on, in 2016 another set of norms were laid down by the UGC. The norms stated the guidelines for entry into the M.Phil.,

Intake Capacity, Supervisors Eligibility and Intake, Duration, Mode of Study etc. As per the latest norms, no university in India is allowed to offer M.Phil. program in Distance Education/ Correspondence Mode/ Private Mode/ Online Mode etc. Only Regular and On-Campus mode is allowed with Full-Time and Part-Time option. M.Phil. in India offered in all kind of Universities and they have also permitted in some other HEIs and Research Centers (including colleges) to offer the program of study [3], [6], [11], [12].

As M.Phil. program is offered in Science, Humanities, and Commerce stream and only Master's Degree holders are able to join the program if they wish to move $\mathrm{PhD}$ via M.Phil. or only interested in M.Phil. program. However, in engineering, there is no scope for M.Phil. and thus after completion of $\mathrm{M}$.Tech/ME students need to go $\mathrm{PhD}$ only and there is no possibility of M.Phil. or any other 'inbetween’ program before $\mathrm{PhD}$ and after M.Tech/ME.

Moreover, in many countries, another Masters degree is available with nomenclature as M.Res (Master of Research) but the stream is not available in India. Hence M.Phil... in many contexts is important and much valuable.

\section{B. Private Universities and M.Phil. Degrees}

In India Private Universities increased since 2005 and before that only few Universities on private basis were established. In recent past, the number of universities touches 279 (as on October, 2017) and the number is still growing. It is worthy to mention that such universities do not have power to affiliate any colleges and institutions but can confer all kind of degrees and diplomas.

The highest number of private universities credited with the state of Rajasthan with 46 Universities; while with 30 Universities Gujarat holds $2^{\text {nd }}$ Position and Uttar Pradesh scored $3^{\text {rd }}$ position with 29 universities in its category. A Detailed list is provided in Table I.

It is worthy to mention that many of these universities are offering M.Phil. Program with 1 Year Full-Time study; while most of the State University offers 2 Years M.Phil. with mostly, part-time mode of study [6]. 
TABLE I PRIVATE UNIVERSITIES IN INDIA (AS ON OCTOBER, 2017)

\begin{tabular}{|c|c|c|}
\hline S.No. & States & No. of Universities \\
\hline 1 & Arunachal Pradesh & 7 \\
\hline 2 & Assam & 5 \\
\hline 3 & Bihar & 2 \\
\hline 4 & Chhattisgarh & 9 \\
\hline 5 & Gujarat & 30 \\
\hline 6 & Haryana & 20 \\
\hline 7 & Himachal Pradesh & 17 \\
\hline 8 & Jharkhand & 7 \\
\hline 9 & Karnataka & 14 \\
\hline 10 & Meghalaya & 8 \\
\hline 11 & Mizoram & 1 \\
\hline 12 & Madhya Pradesh & 24 \\
\hline 13 & Maharashtra & 9 \\
\hline 14 & Manipur & 1 \\
\hline 15 & Nagaland & 3 \\
\hline 16 & Odisha & 4 \\
\hline 17 & Punjab & 15 \\
\hline 18 & Rajasthan & 46 \\
\hline 19 & Sikkim & 5 \\
\hline 20 & Tripura & 1 \\
\hline 21 & Uttar Pradesh & 29 \\
\hline 22 & Uttrakhand & 13 \\
\hline 23 & West Bengal & 9 \\
\hline \multicolumn{2}{|r|}{ Grand Total } & 279 \\
\hline
\end{tabular}

\section{M.Phil. in Private Universities \& Computing Stream}

M.Phil. Program in Indian Private Universities is mainly available with the different nomenclature of IT and Computing Fields. Almost all these universities offer 1 Year Program combined with Coursework and Research Components (i.e. Dissertation/ Thesis). India holds 279 Private Universities and there $\mathrm{PhD}$ program is most common but still many universities offer M.Phil. program in the field. As per the study total, 17 Universities offers M.Phil. in related fields and mainly with following nomenclatures:

1. Computer Science

2. Computer Application

3. Information Technology

Importantly all these specified nomenclatures are available in India in both MSc and M.Tech. degree (i.e. Science and Engineering stream). Hence Engineering Masters holders
(M.Tech./ME) can also grab the opportunity of M.Phil. program in the allied field before their move to $\mathrm{PhD}$; if they wish for. Thus it is an additional benefit to the IT \& Computing students only and this is not common for the other Engineering streams candidates viz. Civil Engineering, Mechanical Engineering etc. As per the study, it is noticed that among the 17 Universities offering M.Phil. in IT and Computing fields one University called Srinivas University, Karnataka offers three M.Phil. programs in the field and combining all the M.Phil. the number touches 19 (i.e. Nineteen M.Phil. program among the 17 Universities out of 279 Universities). A detailed list of the Universities offer M.Phil. in IT and Computing field is depicted in Table II. It is worthy to note that in many states private universities do not have any M.Phil. program in the field and among these states, few important include Assam, Himachal Pradesh, Jharkhand, Meghalaya, Mizoram, Nagaland, Maharashtra, Manipur, Tripura, Uttarakhand, and even in West Bengal. 
M.Phil. as Masters by Research Work Programs in IT \& Computing Fields: A Case Study of Indian Private Universities

TABLE II PRIVATE UnIVERSITIES IN INDIA (AS ON OCTOBER, 2017)

\begin{tabular}{|c|c|c|}
\hline \multirow[t]{2}{*}{ Sl. No. } & \multicolumn{2}{|c|}{ M.Phil. Program at Private Universities in India (IT \& Computing Related) } \\
\hline & Universities & Programs \& Eligibility \\
\hline \multicolumn{3}{|c|}{ Arunachal Pradesh } \\
\hline 1 & Himalayan University & M.Phil.-IT/ Computer Science \\
\hline 2 & North East Frontier Technical University & M.Phil.- IT/ Computer Science \\
\hline \multicolumn{3}{|c|}{ Assam } \\
\hline \multicolumn{3}{|c|}{ Absent } \\
\hline \multicolumn{3}{|c|}{ Chhattisgarh } \\
\hline 3 & Dr. C.V. Raman University & M.Phil.- IT/ Computer Science \\
\hline \multicolumn{3}{|c|}{ Gujarat } \\
\hline 4 & Calorx Teacher’s University & M.Phil.- IT/ Computer Science \\
\hline \multicolumn{3}{|c|}{ Haryana } \\
\hline 5 & NIILM University & M.Phil.- IT/ Computer Science \\
\hline \multicolumn{3}{|c|}{ Himachal Pradesh } \\
\hline \multicolumn{3}{|c|}{ Absent } \\
\hline \multicolumn{3}{|c|}{ Jharkhand } \\
\hline \multicolumn{3}{|c|}{ Absent } \\
\hline \multicolumn{3}{|c|}{ Meghalaya } \\
\hline \multicolumn{3}{|c|}{ Absent } \\
\hline \multicolumn{3}{|c|}{ Karnataka } \\
\hline 6 & PES University & M.Phil.-Computer Applications \\
\hline 7 & Srinivas University & $\begin{array}{l}\text { M.Phil.-Computer Science } \\
\text { M.Phil.-Data Analytics \& Cloud Computing } \\
\text { M.Phil.-Big Data and Business Analytics }\end{array}$ \\
\hline \multicolumn{3}{|c|}{ Madhyapradesh } \\
\hline 8 & A.K.S. University & M.Phil.-Computer Application \\
\hline \multicolumn{3}{|c|}{ Mizoram } \\
\hline \multicolumn{3}{|c|}{ Absent } \\
\hline \multicolumn{3}{|c|}{ Maharashtra } \\
\hline \multicolumn{3}{|c|}{ Absent } \\
\hline \multicolumn{3}{|c|}{ Nagaland } \\
\hline \multicolumn{3}{|c|}{ Absent } \\
\hline \multicolumn{3}{|c|}{ Absent } \\
\hline \multicolumn{3}{|c|}{ Manipur } \\
\hline \multicolumn{3}{|c|}{ Absent } \\
\hline \multicolumn{3}{|c|}{ Odisha } \\
\hline & Abse & \\
\hline & Punja & \\
\hline 9 & C.T University & M.Phil.-Computer Applications \\
\hline 10 & Guru Kashi University & M.Phil.-Computer Applications \\
\hline 11 & Lovely Professional University & M.Phil.-Computer Applications \\
\hline & Rajastl & \\
\hline 12 & Bhagwant University & M.Phil.-Computer Applications \\
\hline 13 & Sunrise University & M.Phil.-Computer Applications \\
\hline & Sikki & \\
\hline
\end{tabular}




\begin{tabular}{|c|l|c|}
\hline 14 & Vinayaka Missions Sikkim University & M.Phil.-Computer Applications \\
\hline \multicolumn{3}{|c|}{ Tripura } \\
\hline \multicolumn{3}{|c|}{ Absent } \\
\hline 15 & Uttar Pradesh \\
\hline 16 & Shri Ramswaroop Memorial University & M.Phil.-Computer Applications \\
\hline 17 & Shri Venkateshwara University & M.Phil.-Computer Applications \\
\hline \multicolumn{3}{|c|}{ Uttara Khand } \\
\hline \multicolumn{3}{|c|}{ Absent } \\
\hline \multicolumn{3}{|c|}{ West Bengal } \\
\hline \multicolumn{3}{|c|}{ Absent } \\
\hline
\end{tabular}

The study shows that among the States, Uttar Pradesh and Rajasthan hold the first position in terms of highest number of M.Phil. in the IT and Computing field. Such states offer 3 M.Phil. programs each while Arunachal Pradesh has 2 M.Phil. programs in two universities. In Karnataka State total 2 Universities offer M.Phil. programs but four (4) varieties of M.Phil. programs are offered from this state. The Srinivas University offers three M.Phil. programs including the following nomenclature:

1. M.Phil.-Data Analytics \& Cloud Computing

2. M.Phil.-Big Data and Business Analytics

Hence such programs no doubt new but also valuable due to importance in the field of job and placement and higher studies as well.

\section{FINDINGS}

1. M.Phil. programs in India available in the line of UK based universities and offers in Science, Commerce, and Humanities fields. But there is no scope of doing M.Phil. in other fields of study viz. Engineering, Medicine, Dentistry, Pharmacy, Nursing, and Veterinary Science.

2. Though those who are studied Information Technology, Computer Science, and Computer Applications with M.Tech./ MSc award can go for the M.Phil. course. Hence it is an ample opportunity to study M.Phil. course for the engineering Post Graduates in respective fields.

3. M.Phil. program in the field of IT and Computing in Indian Private Universities comes with mainly three nomenclatures viz. Information Technology, Computer Science, and Computer Application. There is no scope of other allied fields with M.Phil. such as Information Science, Information Systems, Information Management, Computer Engineering etc.

4. Most of the Private Universities in India offer M.Phil. program with 1 year full-time study whereas state universities offer 2 years M.Phil. in many cases.

5. India holds 279 private universities and the number is increasing day by day. It is fact that out of these universities 17 are offering M.Phil. program and 19 such programs are noticed.
6. Rajasthan, Uttar Pradesh holds the first position in terms of the number of universities offers M.Phil. programs among the states while Karnataka holds the first position in terms of highest number of M.Phil. programs. The due credit goes to Srinivas University for offering additional new age program with M.Phil. tag mentioned above.

\section{SUGGESTIONS AND CONCLUSION}

Indian Higher Education system is changing rapidly and many universities now started the M.Phil. program in the field. It is worthy to mention that many universities offer all the levels of programs in IT and Computing i.e. Bachelors, Masters, Masters research (i.e. M.Phil.), Doctoral Degrees leading to $\mathrm{PhD}$. Few of the universities having all the levels of degrees are Lovely Professionals University, Srinivas University etc. It is noted that most of the universities offer M.Phil. in IT and Computing branch with the nomenclature Information Technology, Computer Science, and Computer Application though we need to start program in other fields/ subjects of Information Science, Information Systems, Information Management, Computer Engineering etc and Private Universities may take important initiative in this regard. A significant move is taken by the Srinivas University as well and here many new age programs have been started. The focused M.Phil. with Cloud Computing, Big Data Analytics no doubt a great deal for the candidates interested to move Industry and Academia. Though still in Indian Education System many controversies are exits and people, academia only knows broad fields in this context new age programs may be offered with the following style of degree or specializations viz.

1. M.Phil.- IT/ Computer Application (Cloud Computing)

2. M.Phil.- IT/ Computer Application (Big Data)

3. M.Phil.- IT/ Computer Application (Usability Engineering)

4. M.Phil.- IT/ Computer Application (Internet of Things)

5. M.Phil.- IT/ Computer Application (Human Computer Interaction) etc.

However, said and proposed programs may also offer with the nomenclature of Information Science or Information Systems. But it is better to avid Computer Science tag as 
this field is dedicated to the design and development of Computing systems and internal affairs of Computing. There is a healthy potentiality to offer M.Phil. program in this way and further research work (educational policies) may be taken to bring a new age program, interdisciplinary research, and specializations. Private Universities can take proper steps in this regard as they have contributed a lot in recent past to innovations in education, placement, and research!.

\section{REFERENCES}

[1] Tate, D. S., \& Schwartz, C. L., "Increasing the retention of American Indian students in professional programs in higher education”, Journal of American Indian Education, pp. 21-31, 1993.

[2] Sood, R., \& Adkoli, B. V. "Medical education in India-problems and prospects”, J Indian Acad Clin Med, Vol. 1, No.3, pp. 210-212, 2000.

[3] Kapur, D., \& Mehta, P. B., "Indian higher education reform: From half-baked socialism to half-baked capitalism", Center for international development working paper, pp. 103, 2004.

[4] Supe, A., \& Burdick, W. P., "Challenges and issues in medical education in India”, Academic Medicine, Vol. 81, No. 12, pp. 10761080, 2006.

[5] Tayade, M. C., \& Kulkarni, N. B., "The Interface of technology and medical education in india: current trends and scope”, Indian Journal of Basic \& Applied Medical Research, Vol. 1, No.1, pp. 8-12, 2011.

[6] Gupta, D., \& Gupta, N., "Higher education in India: structure, statistics and challenges", Journal of education and Practice, Vol. 3, No. 2, pp. 17-24, 2012.
[7] Sohani, N., \& Sohani, N., "Developing interpretive structural model for quality framework in higher education: Indian context", Journal of Engineering, Science \& Management Education, Vol. 5, No. 2, pp. 495-501, 2012.

[8] Nambissan, G. B., \& Rao, S. (Eds.), "Sociology of education in India: Changing contours and emerging concerns", New Delhi: Oxford University Press, 2013.

[9] Paul, P. K., Aithal, P. S. and Bhuimali, A., "Computing \& Allied Engineering Domain in India with Reference to Private Universities: A Case Study of Bachelors Programs”, International Journal on Recent Researches In Science, Engineering \& Technology, Vol. 5, No. 11, pp. 51-63, 2017.

[10] Paul, P.K., Aithal, P. S. and Bhuimali, A., (). MCA (Information Science and Management): The next Generation Interdisciplinary Specialization for Better Social Informatics and Digital Humanities Practice. International Journal of Scientific Research in Mathematical and Statistical Sciences,Vol. 4, No. 5, pp. 27-32, 2017.

[11] Paul, Prantosh and Bhuimali, A. and Aithal, P. S. Indian Higher Education: With Slant to Information Technology - a Fundamental Overview. International Journal on Recent Researches In Science, Engineering \& Technology, Vol. 5, No. 11, pp. 31-50, 2017

[12] Paul, P.K., Aithal, P. S. () Growing popularity of Post Graduate Diploma programs in IT and Computing in Indian Private Universities: An Overview. International Journal on Recent Researches In Science, Engineering \& Technology, Vol. 6 , No. 11, pp. 01-10, 2018. 